\title{
Increased interleukin 6 concentrations in the absence and presence of HIV-1 infection in haemophilia
}

\author{
R Madhok, A Cruickshank, A J Gracie, A Shenkin, G D O Lowe
}

\begin{abstract}
Aims: To measure IL-6 concentrations in asymptomatic HIV-1 antibody positive and negative haemophilic patients and to correlate these with IgG concentrations and CD4 positive cell numbers.

Methods: IL-6 concentrations were measured by bioassay in stored serum from a prospective cohort of haemophilic patients in whom immunoglobulins and $T$ cell subsets had been determined. Values of IL-6 and immunoglobulins were also correlated with severity of liver disease.

Results: IL-6 concentrations were raised in haemophilic patients independent of HIV-1 antibody status. In HIV-1 antibody positive patients there was no correlation between IL-6 concentrations and CD4 positive cell numbers, but there was a correlation with IgG $(r=0.4 ; p=0.05)$. In HIV-1 antibody negative patients there were no significant correlations.

Conclusions: Haemophilic patients have increased IL-6 concentrations; in HIV-1 positive patients this is independent of the decline in $\mathrm{CD} 4$ cell count. The raised concentrations do not correlate with the clinical severity of liver disease.
\end{abstract}

Haemophilic patients with human immunodeficiency virus-1 (HIV-1) infection have increased numbers of partially and fully activated $B$ cells. ${ }^{1-3}$ In HIV-1 antibody negative patients most have normal proportions of resting, activated, and fully differentiated $B$ cells. ${ }^{12}$ However, in some patients with liver disease there is a greater proportion of partially activated compared with resting B cells. ${ }^{24}$

$B$ cell growth and differentiation is regulated by a number of soluble factors. Functional studies using recombinant factors indicate that individual cytokines activate resting B cells, induce proliferation of activated B cells, regulate isotype expression ${ }^{7}$ or induce immunoglobulin secretion. ${ }^{8}$ The terminal differentiation of $\mathbf{B}$ cells is mediated by interleukin-6 (IL-6). ${ }^{8}$

IL-6 was first identified in the culture supernatant fluid of phytohaemagglutinin stimulated peripheral blood mononuclear cells. ${ }^{9}$ Although initially isolated from a transformed T cell line, IL-6 is also secreted from other cell types. ${ }^{10}$ Within the hamatopoietic system monocytes seem to be the principal source. ${ }^{11}$

Although initially thought to be a B cell restricted cytokine, it has become apparent that IL-6 has effects both on haematopoietic and non-haematopoietic cells. These include: weak anti-viral activity ${ }^{10}$; granulocyte macrophage colony stimulating activity ${ }^{12}$; cytotoxic $\mathrm{T}$ cell differentiation ${ }^{13}$; and induction of acute phase protein synthesis. ${ }^{14}$

We measured serum IL-6 concentrations in haemophilic patients treated with clotting factor concentrates. The effects of HIV-1 infection and liver disease were considered independently. Serum IL-6 concentrations were also correlated with serum immunglobulin concentrations, $\mathrm{T}$-helper/inducer $(\mathrm{CD} 4+)$ and $\mathrm{T}$ suppressor/cytotoxic $(\mathrm{CD} 8+)$ cell numbers.

\section{Methods}

Sixty adult haemophilic patients who formed part of a prospective cohort of 133 patients, treated with a blood product since 1980 from one centre, were studied. Nineteen of the 22 patients known to be antibody positive for HIV-1 infection by western blotting were also included. The case notes were reviewed and the following additional information sought: (1) the mean annual dose of clotting factor concentrate used over the previous six years; (2) grade of liver disease based on the algorithm shown in fig 1 . Heterosexual males with no risk factors for HIV-1 infection matched for age were used as controls.

Peripheral blood mononuclear cells were separated from anticoagulated venous blood over a sodium metriazide density gradient. Peripheral blood mononuclear cells were stained with OK-T4 and OK-T8 monoclonal antibodies (Ortho Pharmaceuticals, Raritan, New Jersey, USA) and counted on a fluoresence activated cell sorter (Becton Dickinson, Sunnyvale, California, USA).

Serum from the same blood sample was tested for IgG, IgM and IgA concentrations by immunoturbidmetry and an aliquot stored at $-70^{\circ} \mathrm{C}$.

7TD1 hybridoma cells were used. ${ }^{15}$ The cells were maintaind in DMEM supplemented with $10 \%$ heat inactivated fetal calf serum, $1.5 \mathrm{mM}$ L-glutamine, $0.24 \mathrm{mM}$ L-asparagine, $0.55 \mathrm{mM} \mathrm{L}$-arginine and hybridoma growth factor in a $8 \% \mathrm{CO}_{2}$ /air humidified atmosphere at $37^{\circ} \mathrm{C}$.

The assay was carried out in 96 well flatbottomed well microtitre plates. Each well contained 2000 7TD1 cells and serial two-fold dilutions of test serum which had been heat inactivated at $56^{\circ} \mathrm{C}$ for 30 minutes. Each dilution was tested in triplicate. Proliferation was assessed after 48 hours by a colorometric 




Figure 1 Serum alanine aminotransferase (ALT) activities over the previous five years were retrieved. Al patients had $\geq$ two estimations a year.

1 Patients were divided into those with normal and raised $A L T$ values $(\geq 75 \mathrm{IU} / \mathrm{ml}$ ).

2 Case notes of 16 patients with normal ALT were further reviewed and divided into those with biochemical (a rise in serum ALT above twice the upper limit of normal on at least two occasions, at least two weeks apart, in the absence of any other cause) or clinical (biochemical $N A N B$ associated with clinical jaundice or systemic symptoms) evidence of NANB infection prior to the five years reviewed (grade 2) or those without previous $N A N B$, as defined above (grade 1).

3 Forty four patients had $\geq$ one ALT estimation of $\geq 75$ IUlml. In four this was due to NANB infection, as defined above, during the five years reviewed. Prior $A L T$ results confirmed this (grade 3 ).

4 All remaining patients were classified as having chronic liver disease (grade 4).

method. ${ }^{16}$ Test sample IL-6 concentrations were calculated in units $/ \mathrm{ml}$ calculated from a standard curve using recombinant IL-6 (gift of Dr L Aarden, Leuven, the Netherlands).

The medians and interquartile range were reported. To analyse data between two independent groups the Mann Whitney $U$ test was used. Associations between two continuous variables were calculated by Spearmann rank correlations. Stepwise logistic regression was used to examine correlations between two independent variables (either dichotomous or continuous). ${ }^{17}$

\section{Results}

Forty nine patients had factor VIIIC deficiency and 11 had factor IX deficiency. Fifty

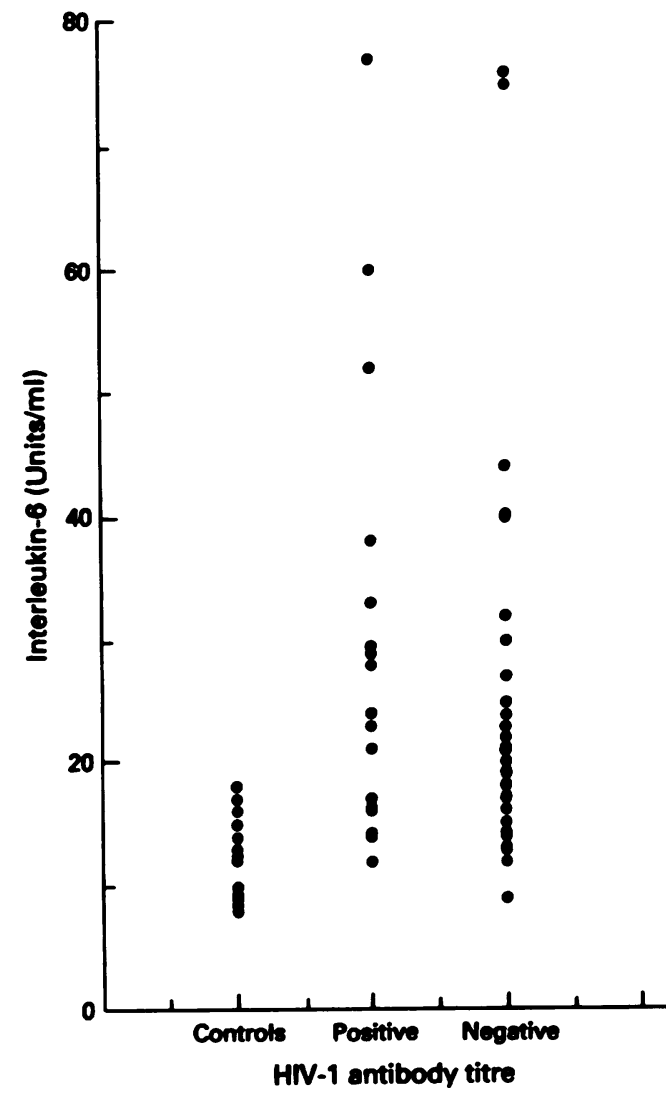

Figure 2 Haemophilic patients, both HIV-1 antibody positive and negative, had significantly higher IL-6 concentrations median $=20 \cdot 5$ Units $/ m l$ (IOR: $15 \cdot 5-29)$ than controls, median = 10.5 Units/ml (IQR: 9-13.5); $p=0.0006$. There was no difference in IL-6 between $H I V-1$ antibody positive, median = 24 Units/ml (IQR: 16-33) and negative, median $=19$ Units/ml $(I Q R:$ 15-24) haemophilic patients

one patients had factor less than $5 \mathrm{IU} / \mathrm{dl}$, eight between 5-10 IU/dl, and one more than $10 \mathrm{IU} / \mathrm{dl}$. The median age of the whole group was 28 years (interquartile range (IQR): $22 \cdot 5-38)$.

Nineteen patients were HIV-1 antibody positive by enzyme linked immunosorbent assay (ELISA) and western blotting. At the time studied serum was stored the median duration of infection was 53 months (IQR: 43-60) and none of the patients had clinical manifestations of HIV-1 infection. The table compares HIV-1 antibody positive and negative patients.

Forty four patients had abnormal liver function tests (fig 1). In HIV-1 antibody positive patients 14 had grade 4 liver disease; and one

\begin{tabular}{|c|c|c|c|c|}
\hline & \multicolumn{4}{|l|}{$H I V-1$ status } \\
\hline & All & Positive & Negative & p Value \\
\hline $\begin{array}{l}\text { Number of patients } \\
\text { Age (years) } \\
\text { Mean annual dose clotting factor (units/annum) } \\
\text { Liver disease grade } \\
\text { CD-4+ cells (cells } / \mathrm{mm}^{3} \text { ) } \\
\text { CD-8 + cells (cells/mm } \mathrm{mm}^{3} \text { ) } \\
\text { IgG (g/l) } \\
\text { IgA (g/) } \\
\text { IgM (g/l) } \\
\text { IL-6 (Units/ml) }\end{array}$ & $\begin{array}{l}60 \\
28(22 \cdot 5-35) \\
37738(13344-65112) \\
3(2-5) \\
571(434-740) \\
447(318-741) \\
13 \cdot 9(12 \cdot 3-18 \cdot 2) \\
1.8(1 \cdot 3-2 \cdot 4) \\
1 \cdot 9(1 \cdot 1-2 \cdot 6) \\
20 \cdot 5(15 \cdot 5-29)\end{array}$ & $\begin{array}{l}19 \\
22(18-35) \\
78698(41564-88371) \\
3(2-4) \\
526(375-648) \\
640(470-883) \\
19(14-23 \cdot 3) \\
1 \cdot 9(1 \cdot 7-2 \cdot 4) \\
2 \cdot 5(1 \cdot 9-3 \cdot 2) \\
24(16-33)\end{array}$ & $\begin{array}{l}41 \\
29(22-35) \\
21878(8557-42224) \\
3(2-5) \\
588(456-789) \\
355(242-540) \\
13 \cdot 4(12-15 \cdot 6) \\
1 \cdot 8(1 \cdot 5-2 \cdot 5) \\
1 \cdot 5(1-2 \cdot 3) \\
19(15-24)\end{array}$ & $\begin{array}{l}0.02 \\
0.001 \\
0.8 \\
0.18 \\
0.001 \\
0.007 \\
0.5 \\
0.008 \\
0.09\end{array}$ \\
\hline
\end{tabular}

$\mathrm{P}$ values calculated for differences in medians between HIV-1 positive and negative haemophilic patients. 
patient had acquired non-A, non-B (NANB) infection in the previous five years (grade 3 ). Three patients had grade 2 and one grade 1 liver disease. Two patients were hepatitis $B$ surface antigen carriers, both were HIV-1 antibody positive.

HIV-1 antibody positive patients had used significantly more clotting factor concentrate per annum compared with HIV-1 antibody negative patients $(p=0.0001)$. There was no correlation between grade or liver disease and mean annual dose of clotting factor concentrate used $(\mathrm{r}=0.3, \mathrm{p}=0.009)$.

Serum immunoglobulin concentrations are shown in the table. Serum IgG and IgM concentrations were significantly higher in HIV-1 antibody positive patients. There were no correlations between IgG $(\mathrm{r}=0.3$; $\mathrm{p}=0.003), \operatorname{IgA}(\mathrm{r}=0.05 ; \mathrm{p}=0.7), \operatorname{Ig} M$ $(\mathrm{r}=0.4 ; \mathrm{p}=0.004)$ and liver disease in the patients studied. The correlations with liver disease in HIV-1 antibody positive patients were: $\operatorname{IgG}, r=0.3(p=0.3) ; \operatorname{IgA} ; r=0.4$ $(p=0.1)$, and $\operatorname{IgM}, r=0.07(p=0.8)$. In HIV-1 antibody negative patients the correlations obtained with liver disease were $\mathrm{IgG}$, $r=0.3(p=0.05), \operatorname{IgA}, r=0.01(p=0.5)$, and IgM, $r=0.06(p=0.7)$.

To determine the relative contributions of HIV-1 infection and liver disease a stepwise logistic regression equation was constructed in which IgG was the dependent variable and HIV-1 infection and severity of liver disease the independent variables. On both forward and backward selection, only HIV-1 infection was retained within the equation $\left(r^{2}=0.33\right)$, coefficient for HIV-1 $=7, t=5 \cdot 8, \mathrm{p}=0.0002$.

Haemophilic patients had higher IL- 6 concentrations than controls. This was independent of HIV-1 status (fig 2), although values did not differ between HIV-1 antibody positive and negative patients. In HIV-1 antibody positive patients serum IL- 6 concentrations showed a correlation with serum IgG $(r=0.4$; $\mathrm{p}=0.05)$, but no correlation with serum IgA $(\mathrm{r}=0.02 ; \mathrm{p}=0.9), \operatorname{IgM}(\mathrm{r}=0.1, \mathrm{p}=0.7)$, or severity of liver disease $(r=0.3, p=0.3)$. There was no correlation with the CD4 + cell count in HIV-1 antibody positive patients. In HIV-1 antibody negative patients no correlations were seen with either immunoglobulin concentrations, CD4 + cell count, or severity of liver disease.

\section{Discussion}

The results of this study show that haemophilic patients have increased serum IL-6 concentrations; this was independent of HIV-1 status. The difference between $\mathrm{HIV}-1$ positive and negative patients just failed to reach significance. This may have been due to the small numbers of HIV-1 positive patients in this cohort, or, alternatively, may reflect the relatively short duration of HIV-1 infection at the time the samples were obtained.

Others have also reported raised concentrations of IL-6 in HIV-1 infection. ${ }^{18}$ Monocytes have been shown to be the principal cells producing IL-6 in peripheral blood. ${ }^{19}$ Raised concentrations, therefore, could be due to HIV-1 infection of monocytes or the result of direct stimulation. ${ }^{18}$ The raised concentrations of IL- 6 explain the shift in the circulating B cell population in HIV-1 infection to greater proportions of partially activated and fully differentiated $\mathrm{B}$ cells in HIV-1 infection. ${ }^{20}$ In keeping with this we noted a correlation between IL- 6 and serum IgG concentrations.

The finding of raised concentrations in HIV1 antibody negative haemophilic patients is in keeping with previous findings of raised immunoglobulin concentrations in haemophilia. Raised IgG concentrations are indicative of progressive liver disease, ${ }^{21}$ but we could not show a correlation between liver disease and serum IL-6 concentrations. A better correlation may have been observed if IL- 6 had been measured in the supernatant fluid of cultured mononuclear cells. In the absence of these values and histological proof of the severity of liver disease, no firm conclusions can be drawn.

In conclusion, the results of this study have shown that haemophiliacs have increased IL-6 concentrations. This was also the case in both HIV-1 antibody positive and negative patients, and there was no difference between these two groups. One consequence of raised IL- 6 concentrations in HIV-1 positive patients may be that acute phase proteins such as $\mathrm{C}$-reactive protein may be poor indicators of infections. Furthermore, we noted a correlation between serum IL-6 and IgG concentrations, but only in HIV-1 antibody positive patients. The raised concentrations in HIV-1 antibody negative patients cannot be entirely explained but may indicate the presence of underlying chronic liver disease.

RM is an Arthritis and Rheumatism Council (UK) lecturer. This study was supported in part by the Scottish Hospital Endowments Research Trust.

1 Biagotti R, Giudizi MG, Almerigogna F, et al. Abnormalities of in vitro immunoglobulin production in apparently healthy haemophiliacs: relationship with alterations of $T$ cell subsets and with HTLV-III seropositivity. Clin Exp Immunol 1986;63:354-8.

2 Ragni MV, Ruben FL, Winklestein A, et al. Antibody response to immunization of patients with haemophilia with and without evidence of HTLV-III infection. $¥ \mathrm{Lab}$ Wlin Med 1987;109:545-9.

3 Siamsoedin-Virser EJM, Heigen CJ, Zegers BJM, Stoop JW. Sjamsoedin-Virser EJM, Heigen CJ, Zegers BJM, Stoop JW. Defect in B cell function in HTLV-III/LA

4 Madhok R, Gracie JA, Forbes CD, Lowe GDO. B cell dysfunction in haemophilia in the absence and presence of HIV-1 infection. Thromb Haemostas 1991;65:7-10.

5 Oliver K, Noelle RJ, Uhr JW, Krammer PH, Vitelta ES. B cell growth factor is a differentiation factor for resting $B$ cells and may not induce growth. Proc Natl Acad Sci USA 1985;82:2465-7.

6 Sharma S, Metha S, Morgan J, Maizel A. Molecular cloning and expression of B-cell growth factor gene in Escherichia and expression of B-cell growth

7 Snapper CM, Paul WE. Interferon-x and B cell stimulatory faper CM, PaulW. Inle Is isotype production. Science 1988;236:944-7.

8 Muraguchi A, Hirano T, Tang B, et al. The essential role of B cell stimulatory factor 2 (BSF-2/LL-6) for the terminal B cell stimulatory factor 2 (BSF-2/IL-6) for the terminal
differentiation of B cells. $\mathcal{E}$ Exp Med 1988;167:322-44.

9 differentiation of B cells. $\mathcal{F}$ Exp Med 1988;167:322-44. Hirano T, Yasukawa $\mathrm{K}$, Harade $\mathrm{H}$, et al. Complementary
DNA for a novel human interluekin (BSF-2) that induces B DNA for a novel human interluekin (BSF-2) that induces B
lymphocytes to produce immunoglobulin. Nature lymphocytes to

10 Zilberstein A, Ruggieri R, Korn JH, Ravel M. Structure and expression of cDNA and genes for human interferon-B2, a distinct species inducable by growth stimulatory cytokines. Eur Mol Biol Organ f 1986;5:2529-37.

11 Kato K, Yokoi T, Takano N, et al. Detection by in situ hybridization and phenotypic characterisation of cell expressing IL-6 mRNA human/stimulated blood. F Immunol 1990;144:1317-22. 
12 Wong GG, Witek-Gianotti JS, Temple PA, et al. Stimulation of murine hemopoetic colony formation by human IL-6. $\mathcal{J}$ Immunol 1988;140:3040-4.

13 Takai Y, Wong GG, Clark SC, Burakoff SJ, Herrmann SH. $B$ cell stimulatory factor-2 is involved in the differentiation of cytotoxic $T$ lymphocytes. F Immunol 1988:140:508-12.

14 Gauldie J, Richards C, Harnish P, Lansdrop P, Baumann H. Interferon B2/B-cell stimulatory factor type 2 shares identity with monocyte-derived hepatocyte-stimulating factor and regulates the major acute phase protein response in
liver cells. Proc Natl Acad Sci USA 1987;84:7251-5.

15 Van Snick J, Vink A, Cayphas S, Vyttenhove C. InterleukinVan Snick J, Vink A, Cayphas S, Vyttenhove C. Interleukin-
HP1, a T cell derived hybridoma growth factor that supports the in vitro growth of murine plasmacytomas. $f$ Exp Med 1987;165:641-50.

16 Mossman T. Rapid colorimetric assay for cellular growth and survival: application to proliferation and cytotoxicity assay. F Immunol Methods 1983;65:55-63.
17 Armitage P, Barry G. Statistical methods in medical research, 2nd ed. Oxford: Blackwell Scientific Publications, 1985.

18 Nakajima K, Martinex-Maza O, Hirano T, et al. Induction of interleukin 6 (BSF-2/IFNY BZ) production by the human immunodeficiency virus (HIV). I Immunol 1989;142:144-7.

19 Kato K, Yokoi T, Takano N, et al. Detection by in-situ hybridization and phenotypic characterization of cells expressing IL-6 mRNA in human stimulated blood. $\mathcal{F}$
Immunol 1990;144:1317-22.

20 Lane HC, Masur H, Edgar LC, Whalen G, Rook AH, Fauci AS. Abnormalities of $B$ cell activation and immunoregulation in patients with the acquired immunodeficiency syndrome. N Engl f Med 1983;309:453-8.

21 Hay CRM, Preston FE, Triger DR, Greaves M, Underwood JCE, Westlake L. Predictive markers of chronic liver disease in haemophilia. Blood 1987;69:1595-9. 